\title{
The Cash Waqfs Debate of 1545-1548: Anatomy of a Legal Debate at the Age of Süleyman the Lawgiver
}

\author{
Hasan Karataş*
}

\begin{abstract}
Öz: Kanuni devrinde para vakıfları etrafında dönen hukuki polemik Osmanlı ilmiyesinin tekamülü açısından son derece önemli bir dönüm noktasıdır. Bu makalede bu hukuki polemiğin taraflarının şahsi hikâyelerine yoğunlaşılarak, tartışmanın fikrî temellerinden ziyade siyasi ve sosyal tarafları ön plana çıkarılmaya çalışıımışıı. Para vakıfları münazarası, önemli bir toplumsal mesele ile doğrudan bağlantılı olması münasebetiyle asla basit bir akademik tartışma olarak kalmadı. Değişik ilmi argümanların arkasında muhtelif siyasi ve toplumsal aktörler saf tuttular. Zaman zaman ulema arasındaki şahsi meseleler de bu tartışma bağlamında su yüzüne çıktı ve bu münazaranın neticesi akademik prestijin çok ötesinde menfaatler içermekteydi. Para vakıfları polemiğinin galibleri Osmanlı ilmiyesinin oluşumunda söz sahibi oldular. Ve bu tartışma Osmanlı ulemasının politik aktörlere evrilmelerinde önemli bir kilometre taşı tesis etmiştir.
\end{abstract}

Anahtar Kelimeler: İlmiye, İlişki Ağları, İslam Hukuku ve Bankacılığı, Kanuni Sultan Süleyman, Vakıf, Ebu's Suud, Çivizade Mehmed Muhyiddin Efendi

\begin{abstract}
The cash waqfs debate of the mid-sixteenth century is indicative of a very critical phase in the development of the Ottoman legal tradition and scholarly establishment. By bringing the personal stories of the major figures to the fore, this article focuses on the social and political aspect of the debate rather than its intellectual content. As a public legal debate related to a critical social issue the cash waqfs discussion was more than simple scholarly exchange. Behind the points distinguishing different scholarly opinions lined there were sundry social and political groups that struggle for the control of resources. Occasionally personal issues between scholars used to surface in the form of an academic debate. And the outcome of the debate endowed the winning party more than a scholarly prestige. At such a critical juncture in the evolution of the Ottoman scholarly/legal establishment, the winners of this particular legal debate came to be very influential in the formation of the ilmiye. Finally, this debate marked an important turning point in the transformation of the Ottoman ulama from homo academicus to homo politicus.
\end{abstract}

Keywords: Ottoman Scholarly Establishment, Networks, Islamic Law and Finance, Süleyman the Lawgiver, Waqf, Ebu's Suud, Çivizade Mehmed Muhyiddin Efendi

* New York University

Atıf@: Karataş, H. (2010). The Cash Waqfs Debate of 1545-1548: Anatomy of a Legal Debate at the Age of Süleyman the Lawgiver. Insan ve Toplum, 1 (1), 45-66. 


\section{Introduction}

In the mid-sixteenth century Istanbul a public legal debate over the cash waqfs, i.e. the practice of endowing cash for charitable purposes, erupted among the learned circles of the Ottoman Empire. It was during the reign of Süleyman the Lawgiver [better known as the Magnificent in Western circles] and the empire was at the zenith of its power. It was again in the course of these decades most of the earlier Ottoman social, political and religious practices, which were the product of frontier ghazi ethos, were either consolidated or eliminated, through an elaborate and a century long process of selection, regulation, systematization, legitimization and codification. This development had origins in the reign of Mehmed II (1451-1481) just after the conquest of Istanbul, and continued through the reigns of Bayezid II and Selim I. Süleyman I, with his gifted scholars and bureaucrats such as Kemalpaşazade (d.1534), Ebu's Suud (d.1575), Celalzade Mustafa (d.1565) etc. who gave these institutions their final and imperial shape. The cash waqfs debate erupted right in the middle of this period, just after Ebu's Suud's appointment to the office of Şeyhülislamlık in 1545.

This article is a micro narrative of the cash waqf controversy of 1545-1548. The reason for isolating this debate is that the parties in this cash waqf debate had different concerns and worldviews than those of later seventeenth century activists. ${ }^{1}$ And they should be treated within the multi-layered context of the early decades of Süleyman the Lawgiver's reign. One should locate this controversy within following contexts: the systematization and codification of Ottoman law, the formation of distinctly Ottoman orthodoxy and orthopraxy, and finally the networks of personal relationships within the increasingly politicized scholarly establishment (ilmiye).

\section{The Approaches}

Thanks to its timing and focus, the cash waqf controversy in question is essential in many respects and can be treated with multiple approaches. For instance, from the viewpoint of social and institutional history, the debate is critical in understanding the development of one of the basic social institutions of the Ottoman Empire, namely the waqfs. Any historian interested in the waqfs of the Ottoman Empire cannot ignore the role of cash-waqfs and the controversy around them. It is also related to the development of another Ottoman institution, namely the ilmiye, since the main characters of the story include three Şeyhülislams and a military judge. Secondly, there is a financial aspect to the controversy, as the cash waqfs were major sources of small scale con-

1 Mandaville further notes that some of the modern researchers employ the approach of seventeenth century authors to sixteenth century in their accounts of the events of 1545-1548 (Mandaville, 1979). An example to this tendency is best seen in the cited works of Halil Inalcik and Neş'et Cagatay below. 
sumer credit for the middle classes of the Empire for a long period of time, especially during the inflationary period of late sixteenth and early seventeenth centuries.

Most important of all, the legal aspect of the controversy is really significant, especially in terms of pursuing the breaks and the continuities within the formation of the Ottoman legal tradition, which flourished under frontier conditions. Endowing movables, especially cash to waqfs was regarded invalid by most of the founding fathers of the four major Islamic schools of law, let alone the permissibility of charging interest out of them. The Ottoman scholars, by sanctioning this practice, without completely stepping out of the Hanafi legal framework once again demonstrated that the Islamic law is more flexible than it was thought to be and they were capable of contributing to its development. The arguments and the terminology put forward by both sides of this controversy can lead historians to the mindset of the Ottoman jurists, and unearth how they perceived and manipulated the Islamic legal tradition and adapted it according to the necessities of time. In short, the cash waqf controversy of 1545 is a field where social, institutional, legal and financial histories of the Empire converge in a way that could open the mental world of the Ottomans to modern researchers.

However, this article will take on a different approach to this controversy. Here an additional aspect of this controversy, i.e. the personal and contingent side of the ilmiye politics in the Ottoman Empire will be narrated. In other words, I will focus on the personal histories of the main characters of the debate rather than their arguments. And I will deal with the inner politics of the nascent Ottoman ilmiye hierarchy, by speculating on the personal aspect of the network of relationships both among the ilmiye and with the rest of Ottoman body politic. This way of approaching to the controversy is crucial in liberating our understanding of the Ottoman intellectuals from the determinism of larger historical trends and institutions, and in revealing the human condition involved in historical change.

Unlike most of the studies on the controversy, this paper will be a micro narrative of the events surrounding 1545-1548. Çivizade Mehmed Muhyiddin Efendi (d. 1547), an ex-Şeyhülislam who persistently opposed the laxity of his colleagues in legal matters, will be occupying the center stage, instead of Ebu's Suud Efendi. In addition to this, another important character in the story, Fenarizade Muhyiddin Efendi (d. 1548), again an ex-Şeyhülislam advocating cash waqfs will be introduced. Apparently the careers of these three scholars intersected in many points long before the eruption of the controversy, as one inquires their educational and professional backgrounds. For example, Çivizade had to wait for two years to be appointed as a professor to the Sahn Medrese, simply because Ebu's Suud was insistent on not giving up that post until 1525. In another instance, Kemalpaşazade requested the Sultan to order the execution 
of Çivizade, because he was convinced by Fenarizade that Çivizade had slighted him. Such relationships were definitely influential in later decisions of these scholars.

For instance, Sofyalı Bali Baba (1547), an important contributor to the debate, asserts in his letters to the Sultan that Çivizade aims to take the revenge of the ulema's opposition to his earlier legal opinions -an opposition, which eventually caused his dismissal from the Şeyhülislamlık. This evidence confirms that, sometimes personal feuds are more influential on the ulema's decisions than professional concerns. Nevertheless to what extent personal affairs of the ulema were ultimately decisive in their legal opinions and judicial careers is a question that needs to be answered by more documentation, hence with more plausible speculation.

\section{The Sources and the Literature}

Primary sources of this debate can roughly be divided into two as academic evidences and documentary materials. The academic evidences include scholarly treatises, legal opinions, personal letters and rejoinders authored by the prominent ulema, and the chronicles and biographical dictionaries of the Ottoman intellectuals before and after the controversy. Kemalpaşazade's Risāle fĩ cevāz-i vaķfi'd derāhim, Ebu's Suud's Risāle fĩ vakfi'l menķül and Birgivi Mehmed's Es-seyfu-l śarim can be listed among the scholarly treatises that were written in a very technical legal language. Another example might be the fetva collection of Ebu's Suud, Ma'rūzāt, which includes not only Ebu's Suud's legal opinions but also the counter opinions of the others. Biographical dictionaries such as Taşköprüzade Ahmed İsamüddin's (d. 1561) al-Şak̦ā'ik, al-nu'mānīya fĩ 'ulamā al-dawla al-'Osmānìye, Mehmed Mecdi's Hadāiks al şaķā'ik (d. 1590-91) and Mahmud Süleyman el-Kefevi's (d. 1582) Katā'ib a'lām al-aǵyār min fukahā maźhab al-Nu'mān al-muǵtār are important sources for the historical development of the discussion as well as general histories such as those of Lütfi Paşa's (d. ca 1563) Āsafnāme and Mustafa Ali's (d. 1598-99) Künh'ül aǵbār.

In mapping out the ulema networks of this period, Taşköprüzade's al-Şaķá'ik is especially important. ${ }^{2}$ His work contains the biographies of 502 scholars and Sufis (including himself) who lived in the reigns of the first ten Ottoman Sultans. Taşköprüzade, as the progeny of an old scholarly family, had an access to a mine of knowledge untapped before, which makes his work a credible and critical source for the period. Ottoman biographical dictionaries, when properly contextualized and cross-checked with each other, communicate more than biographical data, and also offer significant information about the contemporary mentalities, perceptions and especially the

2 In this study the late sixteenth century translation of this work, that of Mehmed Mecdi will be referred. See (Mehmed Mecdi (d. 1590-91), 1989). 
scholarly and Sufi networks. The general tendency among the Ottomanists is to treat these sources as modern reference works by limiting their research with a particular biographical entry and placing too much trust on the information provided. However a more holistic treatment is required. One usually finds information about a scholar in the entries about other people. Such an approach also reveals the author's attitude towards particular social groups, networks and even sultans.

Documentary materials on the other hand are composed of court records, imperial decrees, endowment deeds and waqf survey registers. As the cash waqf controversy was public policy issue on which, neither military judges nor Şeyhülislams had any executive power, Süleyman I issued two imperial decrees first prohibiting the practice then lifting the ban in 1545 and 1548 respectively. The copies of these imperial decrees can be found in El-Kefevi's account as well as in Kanuni Devri Kanunnameleri of Ahmet Akgündüz. For the waqf surveys, Barkan and Ayverdi's İstanbul Vakıflar Tahrir Defterleri: 953 (1546) Tarihli provides an important statistical and legal evidence as well as the copy of the endowment deeds of these waqfs. Interestingly enough, some of these endowment deeds were used as proofs of other party's insincerity. For instance Bali Baba writes in his letter to Çivizade that he owns certain copies of cash endowment deeds endorsed by Çivizade himself. ${ }^{3}$

A comprehensive evaluation of primary sources is provided in the introduction of Richard Repp's The Mufti of Istanbul, which takes on an institutional historian's approach to the development of the office of Şeyhülislamlık until the mid-sixteenth century (Repp, 1986). He provides very revealing details of the personal relationships between the prominent ulema, yet understandably most of his conclusions are confined to the institutional development of the office of Şeyhülislamlık. Another secondary source is Jon Mandaville's frequently referred study of cash waqf controversy in question. Mandaville provides the arguments of both sides of the controversy with long quotations and subjects them to a very clear examination. In the final analysis he explains the controversy in terms of a tension between the liberal majority and the conservative minority within the Ottoman ilmiye hierarchy. Lastly Tahsin Özcan deals with the controversy at length, in the introduction of his recent study of the cash waqfs of Üsküdar during the reign of Süleyman I. He also introduces an important character to the story, who was omitted in other studies, namely Fenarizade Muhyiddin Efendi (d. 1548), the predecessor to Ebu's Suud Efendi in the office of Şeyhülislamlık. Özcan further offers all of the letters of another important character Sofyalı Bali Baba (d. 1547 ) in a comparative way, which proves to be particularly helpful because Bali Baba employs different styles and provides a variety of information in accordance with the addressee of the letter.

3 Çivizade's reply is worth noting: “Ol zamanda vakıf olmadım idi, şimdi fesadına vakıf oldum men' eyledim." (Özcan, 2003: 41) 
Apart from these secondary sources, the articles of Halil Inalcik on the capital formation in the Ottoman Empire, of Murat Çizakça on the cash waqfs of Bursa, of Ronald Jennings on the loans and credits in the provincial courts, and of Neşet Çağatay on the history of the riba and interest concept are also important works that are essential in understanding the multiple aspects of the controversy (Çağatay, 1970; Çizakça, 1995; Inalcik, 1969; Jennings, 1973). Lastly the general works on waqfs and the history of finance such as Murat Çizakça's History of Philanthropic Foundations, Ahmet Akgündüz's İslam Hukukunda ve Osmanlı Tatbikatında Vakıf Müessesesi, and Şevket Pamuk's Monetary History of the Ottoman Empire; and the monographs of Colin Imber on Ebu's Suud and of Abdulkadir Altunsu on the Ottoman Şeyhülislams are additional studies that treat cash-waqfs in related chapters (Altunsu, 1972; Imber, 1997).

\section{The Debate of 1545-1548}

Cash waqfs or evkāf-ı nukūd as they were called by the Ottomans, was becoming increasingly frequent act of piety in the Ottoman Empire since the mid-fifteenth century. Secondary literature on the cash waqfs differ on the origins of this practice, yet all of them agree that it became widespread in the last quarter of the fifteenth century and reached its most widespread use in the seventeenth century. ${ }^{4}$ This practice had been approved by the Ottoman kadis and muftis long before the outbreak of the controversy in 1545. For instance, in his aforementioned treatise Kemalpaşazade, the prominent Şeyhülislam of early sixteenth century endorses the practice in question. Another example might be, as Tahsin Özcan notes, the cash endowment deed (vakfiye) of Şeyhülislam Sadi Çelebi (d. 1537), which carries the signature of Ebu's-Suud Efendi, then the military judge of Rumeli. ${ }^{5}$ Mandaville also quotes most of the earlier Ottoman ulema, deliberately staying silent in the cash waqfs issue as a sign of their approval (Mandaville, 1979: 293-295). Then at a time between 1545 and 1547, the military judge of Rumeli, Çivizade Şeyh Mehmed Muhyiddin, issued a legal opinion, which suggested the prohibition of this practice. ${ }^{6}$

4 For instance, Mandaville dates the earliest cash waqf back to 1423 by certain Yağcı Hacı Muslihuddin, by referring the works of Gökbilgin and Ayverdi-Barkan. He further provides a chart indicating the gradual increase in the establishment of cash-waqfs since that time (Mandaville, 1979: 290).

5 Özcan notes that it is very hard to construct a precise time table of legal works about cash-waqfs before the famous debate of the mid-sixteenth century took place. He further notes that there is no direct reference to the issue of the endowment of cash in the contemporary compilations of Islamic law, such as Mülteka, Dürer, Hidaye and Kadıhan. Apparently we owe the documentation of this discussion largely to the provocative critics of Çivizade, which were later highly politicized (Özcan, 2003: 29).

6 Mandaville notes that he could not find the original copy of Çivizade's fetva. But Mandaville has Ebu's Suud's counter fetva which was quoted by Çivizade in his rejoinder (Mandaville, 1979: 296). 


\section{Çivizade: A Dissident ex-Şeyhülislam}

El-Kefevi (d. 1582), a contemporary author, recounts the incident as follows;

"The Şeyhülislam Şeyh Muhammed b. Molla Çivi used to maintain the lack of validity of making waqfs of dinars and dirhems, saying 'The validity of it [rests upon] a weak authority, and most of the mujtahids agreed that [the practice] is not valid. Whoever undertakes the administration (khidma) of waqfs not knowing the principles of legal 'transaction' nor complying with the requirements thereof- that leads to the opening of the gates of usury.' He made representations on the question to Sultan Süleyman -Çivizade then kazasker of Rumeli- and the Sultan inclined to his view. A decree went out prohibiting kadis from making waqfs of cash and prohibiting kadis from registering them. Matters proceeded thus < until, before long, Çivizade died." ${ }^{\prime 7}$

Çivizade's reasons for the prohibition of cash waqfs are clear. He questions its validity and argues that the trustees of these waqfs might easily abuse the practice and "open the gates of usury". Legal transaction or mu'āmele-i şer'iyye, a euphemism for loaning at interest was considered permissible by the Ottoman jurists, as long as one complies with its requirements such as loaning at a certain interest rate. However, as the court records suggest, these requirements were constantly being violated, which proves Çivizade to be right in his concerns. ${ }^{8}$ However in order to turn his legal opinion into a law Çivizade had to convince the Sultan. As Heyd (1973: 187) points out, the opinions of the ulema were not legally binding on the kadis, although they were held in high respect at the time. ${ }^{9}$ Apparently the Sultan was convinced by Çivizade's arguments and abolished the practice for the time.

Here, el-Kefevi's use of the title of "Şeyhülislam" for Çivizade is worthy of note. As Repp suggests, it is not clear from the text whether Çivizade raised his objections before or after he was dismissed from his previous post, i.e. the Şeyhülislamlık. El-Kefevi might be using the title simply for identification of or out of respect to Çivizade, who was then the military judge of Rumeli. This is an important detail, especially in terms of revealing the reasons behind Çivizade's controversial move. As it is mentioned above, Sofyalı Bali Baba questions the sincerity of Çivizade's motives by asserting that he had a number of copies of cash waqf deeds endorsed by Çivizade himself and Çivizade is simply trying to get even with the ilmiye establishment. As an answer to Bali Baba's accusations, Çivizade argues that he was not aware of the danger posed by cash waqfs then (Özcan, 2003: 41). There seems to be no other evidence suggesting Çivizade's

Quoted and translated by Repp in (Repp, 1986: 254).

For Ebu's Suud's legal opinions related to the abuses of cash waqfs please refer to (Düzdağ, 1983) Tahsin Özcan also shows that mu'āmele-i şer'iyye was the dominant mode of transaction in Üsküdar cash waqfs (Özcan, 2003: 290).

Repp also discusses the process of submitting legal opinions to the Sultan and turning them into an imperial decree in length (Repp, 1986: 282-283). 
approval or disapproval of the practice in question before his public denunciation of cash waqfs while he was the military judge of Rumeli.

Even if Çivizade had no objections to this practice before, it is evident that when he became the military judge of Rumeli, he was alarmed by a notable frequency in cash endowments, especially in the lands of Rumeli. As it is suggested in contemporary surveys of waqf registers, at the time of Çivizade's appointment to the military judgeship of Rumeli, the increasing amount of cash endowments were posing a serious challenge to the more traditional and universally acceptable land waqfs. According to Mandaville, on the eve of cash waqf controversy, cash endowments became rule rather than an exception and "it could be overlooked no longer" (Mandaville, 1979: 292).' Although Çivizade may have held a critical attitude towards this practice, perhaps because of his other priorities, he did not take an immediate action at that time of his Şeyhülislamlık.

Here a brief introduction of Çivizade Mehmed Muhyiddin Efendi might be useful in terms of revealing his intellectual and professional background. Çivizade has a very intriguing personality and a curious professional career, which make his role in the cash-waqf controversy hardly surprising. For instance, he is the first Şeyhülislam to be removed from the post (Mehmed Mecdi (d.1590-91), 1989: 446). ${ }^{10}$ The immediate reason for his dismissal is not very clear in the primary sources. A contemporary account by Lütfi Paşa (d. c. 1563) asserts that the immediate cause for his dismissal is Çivizade's legal opinion against the permissibility of al-masg 'ala'l guffayn, i.e. performing ritual ablution with footwear rather than with bare feet. El-Kefevi, on the other hand, notes that Çivizade was dismissed because he was zealously devoted to the shari'a that "he went too far in certain problems in the şeriat, opposing the generality (of the ulema) and giving fetvas contrary to their views" (Repp, 1986: 250). He further notes that Çivizade declared the unbelief of the great sheiks such as Ibn'al Arabi and Jalaluddin Rumi (Mehmed Mecdi (d.1590-91), 1989: 447). And during his military judgeship of Anatolia, a group of students complained about Çivizade that he was preventing them from becoming mülazims, i.e. the official candidates to judicial positions. It was Ebu's Suud, the military judge of Rumeli who had been charged with investigation of the matter. In short, Çivizade was already unpopular among the statesmen and his colleagues when he had decided to denunciate cash-waqfs publicly. ${ }^{11}$

10 Although Repp finds this claim questionable, he does not openly reject it. According to Repp, Molla Abdulkerim (d. 1489) was the first Şeyhülislam to be removed from the office, in order to make a room for his successor Molla Hüsrev (d. 1480-1). However Repp agrees with other authors on the importance of Çivizade's dismissal (Repp, 1986: 250).

11 For an example of his conflict with two contemporary scholars see Mehmed Mecdi (d.1590-91), 1989: 447. 


\section{Ebu's suud: A Promising Şeyhülislam at the First Trial of his Career}

In response to the Çivizade's fetva against and the consequent ban on the cash waqfs, the Şeyhülislam of the time who had been recently appointed to the post, Ebu's Suud Efendi, issued a counter fetva:

"Although the citations of books seem to be against the permissibility of akce and filuri awkaf, it is also well known which sources of these books are true and sound. It is recognized absolutely that throughout the lands of the provinces of Rum cash waqf is popular and generally practiced, that most of the awqaf of the mosques and welfare establishments are based on cash, that judges past and present, relying on the aforementioned citations ruled in favor of its validity and irrevocability, and no one has spoken against this. The practice is perfectly sound (sahih) irrevocable (lazim)." (Mandaville, 1979: 297)

Ebu's Suud is the most renowned scholar of the Ottoman history. He is revered by most of the Ottoman writers. Altunsu notes that the Ottomans gave Ebu's Suud many honorific titles such as; the Second Abu Hanifah, Muallim-i Sani (Kemalpaşazade being the Muallim-i Evvel) and Hatimat el-Mufessirin (Altunsu, 1972: 29). He is celebrated for having reconciled customary Ottoman practices and the divine law of Islam, by both modern and pre-modern authors. He was honored by the most magnificent Ottoman Sultan, Süleyman the Lawgiver in multiple occasions. "It was Ebu's Suud whom Süleyman chose to lay the foundation stone of the great Süleymaniye mosque in 1550, and to compose the inscription of the portal on its completion seven years later" (Imber, 1997: 15).

But on October 1545, at the very inception of his thirty brilliant years in the office of Şeyhülislamlık, he was an ordinary, yet promising member of the ilmiye. He had been appointed as the military judge of Rumeli seven years earlier and distinguished himself through his mulazemet reform, i.e. standardizing the registration of the candidates for a position in the learned hierarchy. Nevertheless he was under the pressure of the expectations to fill up the authority gap in the office since the death of Şeyhülislam Sadi Çelebi in 1539.12 The three Şeyhülislams between Sadi Çelebi and Ebu's Suud, were forcefully retired, dismissed, and resigned respectively. In addition to all; there was the risk of involuntary removal from the office. The rule of immunity from dismissal (la-yen azl) was broken by the Sultan for the first time when Çivizade Mehmed Muhyiddin was dismissed.

Nonetheless, Çivizade was not an easy challenge for the young Şeyhülislam. He was fourteen years senior of Ebu's Suud and was definitely frustrated by his dismissal from the office. Despite his early fetvas contrary to general attitude and his unpopular-

12 Repp quotes Mustafa Ali: "When the late Şeyhülislam died, the affairs of the Muftilik (emr-i fetva) fell into disarray and [the office] passed to many persons in a short time. Finally [Ebu's Suud Efendi] became mufti in [9]52 and occupied that high office for thirty years..." (Repp, 1986: 278). 
ity among the ulema and the statesmen, he was still well respected for his learning, piety and sense of duty. Plus, he had very good legal grounds for his objections to the practice of cash waqf, and a brief fetva from Ebu's Suud was not likely to change his point of view (Mandaville, 1979: 298). It was definitely not an easy task for Ebu's Suud to counter the arguments of Çivizade in a convincing manner and rally the rest of the learned class behind himself.

But on the other hand, the practice in question gave Ebu's Suud an upper hand. If they were to debate somewhere else in the Islamic world or in some other time period in Islamic history, Ebu's Suud's chance of getting the support of the majority of the Hanafi ulema was slightly more than nothing. The negative attitude of classical Hanafi authorities towards the endowment of cash is a well documented proof for the argument above. Abu Hanifa and al-Shafii were strictly against the endowment of movables. While Abu Hanifa's students Muhammed and Abu Yusuf supported the endowment of movables, they clearly denounced the cash-waqfs. Only Imam Zufer, who was considered as a weak authority by many, openly acknowledged the permissibility of the cash-waqfs. But Ebu's Suud's audience was the "ulema of the Rum". In the frontier world of the ulema of the Rum, there were more important issues at stake than the literal reading of the classical authorities. ${ }^{13}$ And for Ebu's Suud, it was not painstakingly hard to rally up the rest of the ulema against Çivizade if he could address their unique concerns driven by the frontier conditions. A victory against Çivizade would give Ebu's Suud enough confidence and prestige to prove that he is competent in his new office.

A brief look at the position of the Şeyhülislam vis-à-vis the rest of the learned class might be informative in order to demonstrate how ulema's support was critical for the young Şeyhülislam. As Repp suggests, the role of the Şeyhülislam in the decisions related to public policy and the extent of his power vis-à-vis the ulema and the judges in the early sixteenth century are not accorded with what the meaning of the title of the office suggests. In other words, before the Ebu's Suud's tenure, the office of Şeyhülislamlık was a quassi-independent post (from the judicial hierarchy), which served as a spokesman for the ulema, and whose power largely depended on the personal charisma of the office holder. The power of the office was stemming from the power of the office holder then, not vice versa. Ottoman sultans often preferred the consensus of the ulema over the personal opinion of the Şeyhülislam in public policy matters (Repp, 1986: 215, 283). Thus, Şeyhülislam was supposed to serve as a uniting force in the ilmiye circles, and his effectiveness in the office was to some extent depend

13 Fleischer refers to "Sayyid Sharif Jurjani (1340-1413) [who] had once traveled from Iran to Rum and had praised the determination of frontier scholars to acquire knowledge; but also wrote verses saying that religious learning arose in Arabia, found maturity and stability in Iran, and found its end in Rum because of the prevalence of the customary or non-şer'i legal usage. (örf)" (Fleischer, 1986: 260). 
on his abilities to have the ulema reach a consensus and rally behind him. Çivizade's career was a perfect example to this rule. While serving as Şeyhülislam, he apparently failed to unite the ulema behind his opinions and suffered the consequences. But Ebu's Suud happened to be different than his predecessors. He was more than a judge. His long career during the reigns of four Sultans without very few setbacks suggests that he was a man of remarkable political skill.

Ebu's Suud was aware that a simple fetva would not convince the ilmiye circles against the objections of Çivizade. He knew very well that the power of the argument was crucial in terms of both getting the ulema's support and convincing the Sultan. In order to strengthen his position he wrote a twenty-eight page Arabic treatise, which justifies the practice of cash-waqf. It was a very sophisticated treatise, one written in order to impress the ulema and the statesmen of the time. What comes out from this treatise is an essay proving Ebu's Suud's competence in Hanafi legal sources and in their manipulation to support his position. More importantly, what emerges is an appeal to te'ämül ve te'aruf i.e. continued popular usage, to istihsān i.e. the common benefit of the people, and "to both throughout with a tone of "Let's be practical", an appeal to common sense" (Mandaville, 1979: 298).

\section{Çivizade Strikes Back}

The debate certainly did not end there. Çivizade wrote a rejoinder, which meticulously scrutinizes the citations mentioned in Ebu's Suud treatise and provides his own interpretations. He convincingly argues that Imam Zufar is a weak authority whose permission cannot support the irrevocability of cash-waqfs. And for the popular usage (te'ämül) as a justification of the cash-waqfs, "there is no guide or clarification." Nonetheless an intriguing detail in the incipit which provokes further questions and shows that the prayers in the introduction of Ottoman works should be treated more than just formulaic expressions of piety and gratitude;

"Praise to be God, who puts us among those scholars holding fast with the strongest of the statements of the founding legists, who dedicated us to the path followed by the earliest of the forefathers and to the settlement of doubt which obscures transmission from the past, who blessed us with the power to discriminate between the strong and weak among the jurists. May God preserve us from the discord and dissension which occurs in our time because of extremists (muta'aśśibin), May He brings us together with the founding legist as a group calling truth and falsehood..." (Mandaville, 1979: 300)

Çivizade's use of superlatives such as "the strongest of the statements" and "the earliest of the forefathers" indicates Çivizade's conviction that less strong statements of more recent authorities has been cited by Ebu's Suud. As Mandaville points out, Çivizade submits the authorities cited in the Ebu's Suud's treatise to a painstaking 
scrutiny and declares them as weak. This is obvious. But in the second sentence of the incipit, Çivizade points to the extremists of the time, i.e. muta'aśśibin as the source of discord and dissension. As a scholar accused of being one of them, as documented by el-Kefevi's account of his dismissal above, this may simply be a way of mirroring other party's characterization against them.

However, Çivizade might be trying to distance himself from an actual group of scholars who were labeled as muta'aśsibin by the rest of the learned circles of the Empire. Mandaville calls this group as "the strict constructionist school of legal interpretation" and gives Çivizade's incipit to his rejoinder, as an example to the conservative leanings this group (Mandaville, 1979: 301). According to this group, Mandaville notes, a universally accepted and well established precedent ruling is necessary for further legal speculation. Mustafa Ali, in his classification of the scholars of the time, talks about this group as follows;

"The lowest group [of the ulema], fundamentalists who hold so firmly to the words of the oldest authorities that they refuse to consider that new insights or new works are possible. The sin in the direction of fanaticism and blindness, like the Jews and Christians who refused to acknowledge the authority of the Prophet, and are primarily 'infamous Turks' (Türkän-i Bednäm) ulema who wear the trappings of learning but wear none." ${ }^{14}$

Other historical sources also point out a certain group of scholars who were disdainful of the negligence of the official ilmiye hierarchy in legal matters and of its unpleasant closeness to the political authorities. The story of Muhaşşi Sinan Efendi's refusal of the office of Şeyhülislamlık after Ebu's Suud's death in 1574 might be a good example to this attitude. Muhaşşi Sinan Efendi, a former military judge who had joined the crusade against Çivizade's opinions, refused the offer as "he disdained the heart alluring Züleyha of the world, and through the Inspirer of right guidance, he gave ear to the verse from [the sura of] Joseph, 'Turn away from this'". ${ }^{15}$

But at this point, was one supposed to give up from his moral uprightness as he climbs up the ranks of the ilmiye hierarchy? Is it possible to document a certain understanding of a necessary relationship between the ulema's alleged laxity in religious matters and their close relationship with the secular authorities, among the Ottoman intellectuals? Sofyalı Bali Baba implies a similar link in his letters as he asks Çivizade how he could argue consistency while serving as a military judge on the one hand and prohibiting cash waqfs on the other. ${ }^{16}$ Moreover, as Zilfi effectively puts; Kadizadeli preachers of

15 Quoted from Nev'izade Atai in (Repp, 1986: 304) But again it was Muhaşşi Sinan Efendi who led the funeral prayer of Ebu's Suud (Nevizade Atai (d. 1635), 1989: 185).

16 "Kazasker oldunuz. Mülazımine kadılık verirsin, bu meselede akva-yı akvalden hangi kaville amel eylediniz? Ve kazaskerlikten aldığınız avaid akva-yı akvalden hangi kavil iledir? Talib olanlara kadılık 
the seventeenth century actively and deliberately opposed to religious practices that were permitted by the higher ranks of the ilmiye hierarchy, because they were convinced that the ulema were not strict enough (Zilfi, 1988).

Back to the muta'aśśibin; what sort of opposition to change in Islamic law as a result of independent legal reasoning, falls into the category of ta'aśśub? Who or which institution sets the limits of a conservative opposition in the sixteenth century Ottoman learned world? Çivizade implicitly answers these questions, as he claims; muta'aśśibin are the ones who cause discord and dissension within the ummah. In other words, the consensus of the scholars determines the limits of the opposition to independent reasoning, hence the change in the Islamic law. This is a pretty flexible and circumstantial way of defining the term ta'aśśub and muta'aśśibin, which makes it contingent upon the necessities of the time and the location. And although Çivizade neither considers himself as one of the muta'aśsibin nor wants to be identified as such, it appears that he was perceived as one of the muta'aśsibin by both pre-modern and modern authors, especially in relation to the issues of al-masg 'ala'l guffayn, Sufism and the cash-waqfs.

Here another question arises; how can one have the ulema reach a consensus upon and rally behind his point of view so that he wouldn't be considered fundamentalist? Çivizade believes in "holding fast with the strongest of the statements of the founding legists." That is why his response was very much to the point, yet dry and legalistic as opposed to "Ebu's Suud's rhetoric in the public forum" (Repp, 1986: 301). Ebu's Suud, on the other hand, knew his audience very well. He was certainly aware of the concerns of the Ottoman learned class and addressed them by appealing to common sense and pragmatism while keeping his feet firm within the Hanafi legal framework and cunningly employing the Islamic legal terminology. Ebu's Suud's appeal to pragmatism got many confirmatory responses to from the learned circles of Istanbul. Çivizade was also aware that he was loosing ground and he felt compelled to get the support of the prominent ulema. So he turned to an ex-Şeyhülislam Fenarizade Muhyiddin Efendi in order to get the academic support he needed.

\section{Fenarizade Muhyiddin Efendi's Response}

Fenarizade Muhyiddin Efendi, the immediate predecessor of Ebu's Suud in the office and the great-grand son of celebrated Molla Fenari, held the office Şeyhülislamlık from 1543 till his retirement in 1545. Taşköprüzade notes that Fenarizade was extremely careful about the rights due from man to man (hukūk al-ibād), even to the point of scrupulousness (hadd-i vesvese) Mecdi elaborates this description by adding that

vermek akva-yı kavilden hangi kavil iledir? ...Cem'i ahvaliniz hep fetva ve akva üzerine mi oldu? Heman zaaf nukuda mı münhasır oldu kimen edersin." (Keskinoğlu, 1971: 92). 
Fenarizade never bowed to anything other than mihräb, the prayer niche in the mosques (Mehmed Mecdi (d.1590-91), 1989: 388).

Nevertheless Fenarizade was by no means an apolitical and detached scholar. While he was the military judge of Anatolia, he was charged with the investigation of the Grand Vizier Piri Mehmed Paşa, who was accused of accepting bribes and then was forced to retire after being found guilty. Repp is convinced that Fenarizade was in league with an ambitious vizier, Hain Ahmed Paşa, who later was aggravated by the appointment of İbrahim Paşa to the post of Piri Mehmed Paşa and launched a rebellion in Egypt (Repp, 1986: 269). Repp further quotes Peçevi, who comments on Fenarizade's involvement in the incident as follows;

"[After the investigation had been ordered,] because Fenarizade Muhyiddin Çelebi was Kazasker, he became the müfettiş. Deceived by Ahmed Paşa's false promises and enamored of the regard he would be shown should Ahmed Paşa, in line with custom, become Grand Vizier, he decided a number of points [in a manner] contrary to şeriat, so ruining himself in this world and the next." (Repp, 1986: 269)

Perhaps due to this incident, Fenarizade never got along with the newly appointed Grand Vizier Ibrahim Paşa. Repp recounts an incident in which Fenarizade refused to accept the testimony of İbrahim Paşa on the grounds that the latter was an unmanumitted slave of the Sultan. And when İbrahim Paşa related the incident to the Sultan, Süleyman determined not to interfere, told İbrahim Paşa that he was freed. Even then Fenarizade did not accept İbrahim Paşa's testimony until he himself handed the document of manumission in front of the notables of the divan, an act conceived as a daring humiliation of Ibrahim Paşa. Ironically enough, Fenarizade together with the military judge of Anatolia Kadiri Çelebi, were dismissed from their posts due to his "impertinent" questions to the Sultan about the execution of the Grand Vizier İbrahim Paşa. Sources point out their excessive uprightness (fart-i istikāmet) in these matters as the reason behind their removal (Repp, 1986: 260). It is highly probable that Fenarizade and Kadiri Çelebi raised their objections to the execution of the former Grand Vizier on the grounds that Ibrahim Paşa was a manumitted slave, thus a free Muslim.

These two incidents suggest seemingly contradictory conclusions. On the one hand Fenarizade appears to be part of the political machinations of a former vizier who is notorious for his lack of loyalty, while on the other hand he was dismissed from an important post because he could not internalize the unfairness of the execution of his former enemy. First of all one should never ignore the fact that the contemporary sources are immune to neither the personal agenda of their authors nor to the factional politics of the period. Thus their contradictory statements should be treated carefully. Nevertheless, even if one takes both depictions of Fenarizade as accurate, there is still a way to explain Fenarizade's apparently contradictory attitudes. As Repp 
suggests, Taşköprüzade and Mecdi's praise of Fenarizade as an upright scholar was confined to his private persona as opposed to the political and public persona of Fenarizade that was vilified by Peçevi. Which persona of Fenarizade was highlighted by these authors, on the other hand, depends on their personal agenda. This duality, however does not necessarily point out Fenarizade's schizoid personality but a certain notion of uprightness as a moral quality among the ulema, which could coexist or better combined with political skills for the good of the Islamic community.

At the time of Çivizade's letter to Fenarizade regarding the cash waqfs, their personal relationship was already tense. During his office in the Şeyhülislamlık, Çivizade declared Ibn'al 'Arabi, a Sufi author on whose works members of Fenari family has written and commented upon for generations, as an unbeliever along with Ghazali and Rumi. It is not hard to imagine that Fenarizade enthusiastically joined other ulema in condemning Çivizade's opinion, and causing his consequent dismissal. But their mutual dislike goes long before this incident. When Çivizade was a young student, he went to study under Fenarizade and took up residence in his medrese. But later on Çivizade decided to go back to his former teacher for unknown reasons, an action that was taken as a sign of disrespect by Fenarizade. "So outraged was [Fenarizade] Muhyiddin Çelebi by this slight that he never forgave Çivizade, disparaging him constantly both in his lessons and in his writings." ${ }^{17}$

Fenarizade's attitude towards cash-waqfs is in line with the rest of the ulema, i.e. their permissibility in accordance with the earlier Ottoman ulema and on the grounds of popular usage and common benefit. His style, on the other hand, conveys the severity of the personal dislike between the two scholars; "[Despite the fact that] all of previous ulema had ruled in the validity of akce [endowment] and tens of thousands of endowment deeds had been endorsed, [does Çivioğlu argue that] he knows better than all?"18

\section{Sofyalı Bali Baba: A View from the Periphery}

The ulema of the capital were not alone in their criticism of Çivizade's rulings. An interesting support for the cash waqfs came from the periphery. Outraged by the ban on the cash waqfs, Sofyalı Bali Baba (d.1552) a Sufi şeyh of Halveti order wrote letters

17 One still wonders after all this personal history between two scholars, how could Çivizade expect Fenarizade's academic support on the issue of the permissibility of cash waqfs. There is a slight possibility that Çivizade never asked Fenarizade's opinion on the issue. The only secondary source mentioning Fenarizade's letter to Çivizade,that of Tahsin Özcan, does not provide Çivizade's initial letter to Fenarizade. He only refers to Fenarizade's letter, in which Fenarizade does not specify the identity of the petitioner, although he clearly addresses to Çivizade (Özcan, 2003: 246).

18 "....ve simdiğe değin gelen ulema akçenin sahih olmasına hükmedüp on bin miktarı vakıfnameler yazılup cümlesi bilmeyüp heman Çivioğlu mu bildi..." (Özcan, 2003: 45). 
to Sultan, Çivizade and to some other prominent members of the ilmiye (Keskinoğlu, 1971: 92). Bali Baba was born in Usturumca of modern day Albania, and educated in Istanbul. Although he spent the rest of his life in Sofia, Bali Baba was never far from the intellectual debates of Istanbul. He previously wrote a letter denouncing Şeyh Bedreddin-i Simavi to the Sultan of the time, and authored a refutation to one of Kemalpaşazade's treatises on theology. ${ }^{19} \mathrm{He}$ also accompanied Süleyman I in some of his military campaigns. He was certainly an active and prolific Sufi şeyh, who could not resist joining a discussion that is directly linked to the fate of Islamic establishments in Rumeli.

The exact role of Bali Baba in the development of this discussion is uncertain. In other words, historians don't know whether his letters were actually read by the ulema, Çivizade and the Sultan, and eventually influenced their opinions. There exists even a possibility that Bali Baba did not write letters but just treatises in the form of a letter, as Keskinoglu asserts in his article on pious foundations in Bulgaria. It is however clear that they constitute one of the basic accounts of the controversy. In addition to this, like Mandaville suggests "as the opinion of an educated Ottoman working for the most part outside of the Ottoman governmental establishment, the letters present quite a different and illuminating viewpoint" (Mandaville, 1979: 301). In other words Bali Baba's letters represent a viewpoint of an intellectual who is literally on the field, as opposed to those of Istanbulite intellectuals in their relatively sterile environments. He was from a Turkish settler family in Rumeli and evidently sensitive to the Islamization of the area through Islamic establishments which were largely financed by the cashwaqfs then. In fact, Bali Baba acknowledges his sensitivity in the following lines from his letters: "Ah, Çivizade Efendi had known how Islam was settled in Rumeli, and then he would have known whether or not cash waqfs are wrong!" (Mandaville, 1979: 304).

Bali Efendi's letters are full of interesting remarks and emotionally loaded words that cannot be found easily in the detached and scholastic discourse of the ulema. They reveal how the Ottoman legal and religious jargon has operated in the lower levels or outside of academic establishment. They point out other relevant discussions of the time, such as the permissibility of the use of canon and rifle in combat and show how these discussions were perceived by the learned circles of the province. A brief quotation from Bali Baba's letter might suffice to explain what is meant above;

"...Piety which leads to evil is evil itself. An act which destroys a charitable institution is the act of a kizilbas [heretic]... It is to cut Islam off its roots....Those persons who condemn the cash waqf are also those who claim that a gazi [crusader] who uses a cannon or rifle in combat cannot be called a martyr when he dies in combat... I know more about law (kanun) than you do. What have I got

19 Interestingly enough, Kara does not mention Bali Efendi's role in the cash-waqf controversy (Kara, 1988). 
to fear from you, or from anyone else for that matter save God? I say that your actions go contrary to the sharia, that they are innovations (bid'a), a grievous error, and ignorance." 20

In this piece Bali Baba also sets an upper limit to piety, trespassing of which leads to evil. This definition is closely related to the muta'aśśibin and ta'aśśub discussion above. According to Bali Baba, one could oppose innovation in Islamic law, as long as the results of that opposition are not evil. Otherwise, he is a simply an extremist, i.e. one of the muta'aśsibin.

\section{Conclusion}

Despite the concerted effort of the ulema in support of permissibility of cash waqfs the official ban on cash-waqfs has not been lifted for two years, until after the death of Çivizade in 1547. Çivizade suddenly died on early September of 1547 and buried in Eyüp. It was Ebu's Suud who led the prayers for him. It is very probable that the Sultan, before or after Çivizade's death, was informed about the deteriorating situation of the Islamic establishments in Rumeli, and asked Ebu's Suud for his opinion again. Enforced by the representations of the ulema to the Sultan, in the early May of 1548, an imperial decree went out as follows;

"It has now become a matter of common report that, because the administrators of cash waqfs which have been founded to the present time in the Ottoman lands, and the heirs of the benefactors thereof have through [the operation of the decree prohibiting cash waqfs] many mosques and places of worship have become ruined and untended; and that, since most benefactors have not the disposal of immovables ('akar) with which to create waqfs, [the earlier decree] has been the cause of diminutions of benefactions. For these reasons Molla Abdulkadir, formerly my kazasker and [now] in retirement from the office of Mufti; the Mufti, Molla Ebu's Suud; my [two] kazaskers; Molla Emir Mehmed, the former Anadolu kazasker; and other great Mollas have united in opposition to [Çivizade]; have given fetvas to the effect that waqfs of dirhams and dinars are valid and binding; and have said: 'In matters such as this, there is no harm in acting on the basis of a weak authority.' This has been reported to my imperial presence; and since it is my imperial custom and practice to advance the affairs of the Faith and to strengthen the true shar', my decree has gone forth to this effect, that those benefactors who wish to make benefactions and create waqfs on the basis of that which has been current practice in the Ottoman lands since olden times may establish their waqfs, choosing whether to do so with silver or with gold." ${ }^{21}$

Quoted and translated in (Mandaville, 1979: 303).

21 Quoted from el-Kefevi and translated by Repp in (Repp, 1986: 255). 
Repp makes two conclusions out of the decree above. From the institutional point of view, Repp argues that this incident shows the powerful influence of personality and of argument as opposed to that of the office, as Çivizade's opinion won the day although he was hierarchically inferior to Ebu's Suud. And Süleyman took an active interest in the matters related to the shari'a, to the extent that his opinion was decisive, not those of the ulema. According to Repp, this proves that the Sultan's interest was not confined in the matters of secular law (Repp, 1986: 256). This debate also demonstrates that the Ottoman ulema, by legalizing the cash-waqfs, proved that their frontier legal tradition has matured self confident enough to openly challenge a clear prohibition in the classical Islamic law. Finally, the Ottoman political authority is the real winner of the debate because it appeared as an arbiter between different academic/religious camps; hence stepped outside of the political domain as the holder of the last word on a religio-legal issue.

The main argument of this article, however, is more related to the social and political aspect of the debate rather than its intellectual content. Public legal debates, especially when related to the significant issues such as the cash waqfs, are always more than simple scholarly exchanges. Behind the points distinguishing different scholarly opinions lined were sundry social and political groups that struggle for the control of resources. And sometimes personal issues between scholars surface in the form of an academic debate. In the development of the cash waqfs debate of 1545-48 all of the above factors were influential to some degree. And the outcome of the debate endowed the winning party more than scholarly prestige. At such a critical juncture in the evolution of the Ottoman scholarly/legal establishment, the survivors of this particular legal debate came to be very influential in the formation of the ilmiye. Finally, this debate marked an important turning point in the transformation of the Ottoman ulama from homo academicus to homo politicus.

\section{Bibliography}

Altunsu, A. (1972). Osmanlı şeyhülislamları. Ankara: Ayyıldız Matbaası.

Çağatay, N. (1970). Riba and interest concept and banking in the Ottoman Empire. Studia Islamica, 32, 53-68.

Çizakça, M. (1995). Cash waqfs of Bursa, 1555-1823. Journal of the Economic and Social History of the Orient, 38(3), 313-354.

Düzdağ, M. E. (1983). Şeyhülislam Ebussuud Efendi fetvaları ışığında 16. asır Türk hayatı. Istanbul: Enderun Kitabevi.

Fleischer, C. H. (1986). Bureaucrat and intellectual in the Ottoman Empire the historian Mustafa Ali (1541-1600). Princeton, N.J: Princeton University Press.

Heyd, U. (1973). Studies in old Ottoman criminal law. Oxford: Clarendon Press.

Imber, C. (1997). Ebus-Suud: The Islamic legal tradition. Stanford, Calif: Stanford University Press. 
Inalcik, H. (1969). Capital formation in the Ottoman Empire. Journal of Economic History, 29(1), 97-140.

Jennings, R. (1973). Loans and credit in early 17th century Ottoman judicial records: The sharia court of Anatolian Kayseri. Journal of the Economic and Social History of the Orient Journal de I'histoire economique et sociale de l'Orient, 16(3), 168-216.

Kara, M. (1988). Bali Efendi, Sofyalı. Türkiye Diyanet Vakfı İslam Ansiklopedisi içinde (C. 5, s. 20-21). İstanbul: Türkiye Diyanet Vakfı, İslâm Ansiklopedisi Genel Müdürlüğü.

Keskinoğlu, O. (1971). Bulgaristan'da Türk vakıfları ve Bali Efendi'nin vakıf paralar hakkında bir mektubu. Vakıflar Dergisi, 9, 81-94.

Mandaville, J. (1979). Usurious piety: The cash waqf controversy in the Ottoman Empire. International Journal of Middle East Studies, 10(3), 289.

Mehmed Mecdi (d. 1590-91). (1989). Hadā'iķ al şaķā'ik. İstanbul: Çağrı Yayınları.

Nevizade Atai (d. 1635). (1989). Hadā'iq al-haqāiq fì tekmīla al-shaqāiq. İstanbul: Çağrı Yayınları.

Özcan, T. (2003). Osmanlı para vakıfları: Kanuni dönemi Üsküdar örneği. Ankara: Türk Tarih Kurumu Basımevi.

Repp, R. (1986). The mufti of Istanbul: A study in the development of the Ottoman learned hierarchy. London: Ithaca Press for the Board of the Faculty of Oriental Studies Oxford University.

Zilfi, M. C. (1988). The politics of piety: The Ottoman ulema in the postclassical age (1600-1800). Minneapolis, MN, U.S.A: Bibliotheca Islamica. 


\title{
The Cash Waqfs Debate of 1545-1548: Anatomy of a Debate at the Age of Süleyman the Lawgiver
}

\author{
Hasan Karataş*
}

\begin{abstract}
Keywords: Ottoman Scholarly Establishment, Networks, Islamic Law and Finance, Süleyman the Lawgiver, Waqf,
\end{abstract} Ebu's Suud, Çivizade Mehmed Muhyiddin Efendi

In the mid-sixteenth century Istanbul a public legal debate over the cash waqfs, i.e. the practice of endowing cash for charitable purposes, erupted among the learned circles of the Ottoman Empire. This article is a micro narrative of the cash waqf controversy of 1545-1548. Thanks to its timing and focus, the cash waqf controversy in question is essential in many respects and can be treated with multiple approaches, such as from the viewpoint of social and institutional history or legal studies. However, this article will take on a different approach to this controversy. Here an additional aspect of this controversy, i.e. a more personal aspect of ilmiye networks will be explored. The paper will focus on the personal histories between the main characters of the debate rather than their arguments and attempt at an explanation on the relationships both among the ilmiye and with the rest of Ottoman body politic. This way of approaching to the controversy is crucial in liberating our understanding of the Ottoman intellectuals from the determinism of larger historical trends and institutions, and in revealing the human condition involved in historical change.

Unlike in most of the studies on the controversy, which put Ebu's Suud Efendi on the center stage, this article will focus on Çivizade Mehmed Muhyiddin Efendi (d.1547). In addition to this, another important character in the story, Fenarizade Muhyiddin Efendi (d.1548) will be introduced. Apparently the careers of these three scholars that intersected in many points long before the eruption of the controversy, as one inquires their educational and professional backgrounds; underlines the fact that personal feuds are sometimes more influential factors on the ulema's decisions than their professional ethics.

Cash waqfs or evķāf-ı nuķūd as they were called by the Ottomans, was becoming increasingly frequent act of piety in the Ottoman Empire since the mid-fifteenth century. Then at a time between 1545 and 1547, the military judge of Rumeli, Çivizade Şeyh Mehmed Muhyiddin, issued a legal opinion, which suggested the prohibition of this practice. Çivizade questioned the cash waqfs' validity and argued that the trustees of these waqfs might easily abuse the practice and 'open the gates of usury.'

* New York University 
Apparently the Sultan was convinced by Çivizade's arguments and abolished the practice for then.

Çivizade has a very intriguing personality and a curious professional career, which make his role in the cash-waqf controversy hardly surprising. For instance, he is the first Şeyhülislam to be removed from the post. El-Kefevi notes that Çivizade was dismissed because he was zealously devoted to the shari'a that "he went too far in certain problems in the şeriat, opposing the average ulema and giving fetvas contrary to their views." In short, Çivizade was already unpopular among the statesmen and his colleagues when he had decided to denunciate cash-waqfs publicly.

In response to the Çivizade's fetva against and the consequent ban on the cash waqfs, the Şeyhülislam of the time who had been recently appointed to the post, Ebu's Suud Efendi, issued a counter fetva. Ebu's Suud is the most renowned scholar of the Ottoman history. But on October 1545, at the very inception of his thirty brilliant years in the office of Şeyhülislamlık, he was an ordinary, yet promising member of the ilmiye. Nonetheless, Çivizade was not an easy challenge for the young Şeyhülislam. He was fourteen years senior of Ebu's Suud and was definitely frustrated by his dismissal from the office. Despite his early fetvas contrary to general attitude and his unpopularity among the ulema and the statesmen, he was still well respected for his learning, piety and sense of duty. A victory against Çivizade would give Ebu's Suud enough confidence and prestige to prove that he is competent in his new office. Ebu's Suud was aware of the fact that a simple fetva would not convince the ilmiye circles against the objections of Çivizade. He knew very well that the power of the argument was crucial in terms of both getting the ulema's support and convincing the Sultan. In order to strengthen his position he wrote a twenty-eight page Arabic treatise, which justifies the practice of cash-waqf. It was a very sophisticated treatise, one written in order to impress the ulema and the statesmen of the time.

The debate certainly did not end there. Çivizade wrote a rejoinder, which meticulously scrutinizes the citations mentioned in Ebu's Suud's treatise and provides his own interpretations. Çivizade believed in 'holding fast with the strongest of the statements of the founding legists.' Ebu's Suud, on the other hand, knew his audience very well. He was certainly aware of the concerns of the Ottoman learned class and addressed them by appealing to common sense and pragmatism while keeping his feet firm within the Hanafi and cunningly employing the Islamic legal terminology. Ebu's Suud's appeal to pragmatism got many confirmatory responses from the learned circles of Istanbul. Çivizade was aware that he was losing ground and he felt compelled to get the support of the prominent ulema. So he turned to an ex-Şeyhülislam Fenarizade Muhyiddin Efendi in order to get the academic support he needed.

Fenarizade Muhyiddin Efendi, the immediate predecessor of Ebu's Suud in the office and the great-grand son of celebrated Molla Fenari, held the office of Şeyhülislamlık 
from 1543 till his retirement in 1545. At the time of Çivizade's letter to Fenarizade regarding the cash waqfs, their personal relationship was already tense. During his office in the Şeyhülislamlık, Çivizade declared Ibn'al 'Arabi, a Sufi author on whose works members of Fenari family has written and commented upon for generations, as an unbeliever along with Ghazali and Rumi. It is not hard to imagine that Fenarizade enthusiastically joined other ulema in condemning Çivizade's opinion, and causing his consequent dismissal. But their mutual dislike goes long before this incident. When Çivizade was a young student, he went to study under Fenarizade and took up residence in his medrese. But later on Çivizade decided to go back to his former teacher for unknown reasons, an action that was taken as a sign of disrespect by Fenarizade. "So outraged was [Fenarizade] Muhyiddin Çelebi by this slight that he never forgave Çivizade.

The ulema of the capital were not alone in their criticism of Çivizade's rulings. An interesting support for the cash waqfs came from the periphery. Outraged by the ban on the cash waqfs, Sofyalı Bali Baba (d.1552) a Sufi şeyh of Halveti order wrote letters to Sultan, Çivizade and to some other prominent members of the ilmiye. The exact role of Bali Baba in the development of this discussion is uncertain. In other words, historians do not know whether his letters were actually read by the ulema, Çivizade and the Sultan, and eventually influenced their opinions. However Bali Baba's letters represent the viewpoint of someone who is literally on the field, as opposed to those of Istanbulite ulema in their relatively sterile environments. He was from a Turkish settler family in Rumeli and evidently sensitive to the Islamization of the area through Islamic establishments which were largely financed by the cash-waqfs then.

Despite the concerted effort of the ulema in support of permissibility of cash waqfs the official ban on cash-waqfs has not been lifted for two years, until after the death of Çivizade in 1547. Following his death, an imperial decree enforced by the representations of the ulema to the Sultan, in the early May of 1548 went out to legalize cash waqfs. In conclusion the social and political aspects of the debate are as important as its intellectual content. Public legal debates, especially when related to the significant issues such as the cash waqfs, are always more than simple scholarly exchanges. Behind the points distinguishing different scholarly opinions lined, there were sundry social and political groups that struggle for the control of resources. And sometimes personal issues between scholars used to come into surface in the form of an academic debate. In the development of the cash waqfs debate of 1545-48 all of the above factors were influential to some degree. And the outcome of the debate endowed the winning party more than scholarly prestige. At such a critical juncture in the evolution of the Ottoman scholarly/legal establishment, the survivors of this particular legal debate came to be very influential in the formation of the ilmiye. Finally, this debate marked an important turning point in the transformation of the Ottoman ulama from homo academicus to homo politicus. 